\title{
Gyraulus chinensis (Dunker, 1848) - a new greenhouse species for the Czech Republic (Gastropoda: Planorbidae)
}

\author{
LUBOŠ BERAN $^{1} \&$ PETER GLÖER ${ }^{2}$ \\ ${ }^{1}$ Kokořinsko Protected Landscape Area Administration, Česká 149, CZ-27601 Mělník, Czech Republic, e-mail: lubos.beran@schkocr.cz \\ ${ }^{2}$ Schulstrasse 3, D-25491 Hetlingen, Germany, email: gloeer@malaco.de
}

\begin{abstract}
BERAN L. \& GlÖER P., 2006: Gyraulus chinensis (Dunker, 1848) - a new greenhouse species for the Czech Republic (Gastropoda: Planorbidae). - Malacologica Bohemoslovaca 5: 25-28. Online serial at $<$ http://mollusca.sav.sk> 12-May-2006.

Gyraulus chinensis (Dunker, 1848), a planorbid snail native to South and East Asia and living in small water bodies, has been found in two greenhouses, the first time in the Czech Republic. Its occurrence in other greenhouses in the Czech Republic is possible. Survival of this snail in nature is considered unlikely, but it might be possible in artificially heated environments.
\end{abstract}

\section{Introduction}

Gyraulus chinensis (Dunker, 1848) is a limnic gastropod mollusc of small water bodies (e.g. swamps, rice fields) native to South and East Asia (MEIER-BROOK 2002). Recently it has also been reported from swamps and rice fields in several European countries (Spain, Portugal, Italy, France, the Netherlands), and from thermal springs in Austria (FALKNER 1990), and it has also been introduced to West Africa (BROWN et al. 1999). In Germany it was found near Magdeburg (GLÖER \& MEIER-BROOK 2003), but it is unknown if this population has survived. In other European countries $G$. chinensis is known only from fish tanks and greenhouses (ANDERSON 2005, PROSCHWITZ 2005, STRÄTZ 2005).

In the Czech Republic, the possibility of this species occurring in the wild was briefly mentioned by BERAN (2002), but there are as yet no such records. In their list of species from greenhouses in the Czech Republic, HORSÁK et al. (2004) did not mention this species either.

\section{Material and Methods}

In 2006 L. Beran studied the aquatic molluscs of four greenhouses in Bohemia. The unidentified specimens of Gyraulus, later determined to be G. chinensis, were found in two of these.
Aquatic molluscs were searched for by washing vegetation or sediments through a metal sieve (a kitchen strainer, diameter $20 \mathrm{~cm}$, mesh size $0.5-1 \mathrm{~mm}$ ) in combination with searching on stones and wood. The molluscs, except specimens of $G$. chinensis, were determined by their shells. Specimens of $G$. chinensis were killed with hot water and fixed in $70 \%$ ethanol. They were determined using characters of the shells, the external morphology of the soft parts, and their internal anatomy. The nomenclature follows GLÖER \& ZETTLER (2005).

\section{Results}

Gyraulus chinensis was found in 2006 in Bohemia (western part of the Czech Republic) in the two greenhouses detailed below. Data presented are as follows: latitude and longitude, code of the mapping field for faunistic grid mapping (cf. PRUNER \& MíKA 1996), name of the nearest settlement, description of the habitat, number of individuals, date of investigation, names of investigators.

Locality 1 - 50²6'02" N, 1548'08" E, 5561, Dvưr Králové nad Labem, greenhouse Ptačí Svět (Bird World) in the zoological garden in Dvưr Králové nad Labem, the vegetation in a water channel, 2 specimens (one adult, one juvenile), 4 Feb 2006, lgt. L. Beran, det. L. Beran \& P. Glöer, rev. C. Meier-Brook. 
Locality $2-50^{\circ} 07^{\prime} 22^{\prime \prime} \mathrm{N}, 1^{\circ} 26^{\prime} 57^{\prime \prime} \mathrm{E}, 5852$, Prague, tropical greenhouse Fata Morgana in Prague Botanical Garden, a tropical lake in the Tropical Rainforest Exhibition (temperature: min. $22{ }^{\circ} \mathrm{C}$, optimum $24{ }^{\circ} \mathrm{C}$, $\max .30{ }^{\circ} \mathrm{C}$ ), vegetation and rocky banks of the lake, 8 specimens, 12 Feb 2006, lgt. L. Beran, det. P. Glöer, rev. C. Meier-Brook.

\section{Description of specimens}

Locality 1: The shell of adult specimen was $4.9 \mathrm{~mm}$ in diameter and $1.1 \mathrm{~mm}$ high. Periphery moderately angled without keel or fringe. The surface was not glossy, having growth lines and weakly developed fine spiral striae.

The animal was light grey. The mantle roof showed a distinct pattern which was visible through the shell. Head and foot diffusely grey, with scattered black patches. Tentacles with black tissue internally. Prostate with 12 diverticula. The ratio of preputium length to penial-sheath length was around $1: 1$. Bursa duct long and thin, bursa copulatrix an elongated sphere (Fig. 1). Locality 2: The shells were $3.0-3.9 \mathrm{~mm}$ in diameter and $0.8-0.9 \mathrm{~mm}$ high. The periphery was angled and with a fringe. The surface was not glossy, having growth lines, spiral striae, and a fine reticulate surface sculpture with short hairs which follow the spiral striae.

The animals were light grey. Mantle roof with distinct pattern which was visible through the shell. Head and foot diffusely grey, with scattered black patches. Tentacles with black tissue internally. The ratio of preputium length to penial-sheath length was around $1: 1$. Bursa duct long and thin, bursa copulatrix an elongated sphere (Fig. 2).

At the first site this species was found together with Physella acuta (Draparnaud, 1805) and Ferrissia wautieri (Mirolli, 1960) and at the second site with Galba truncatula (O.F. Müller, 1774), Radix cf. labiata (Rossmäessler, 1835), Physella acuta (Draparnaud, 1805), Planorbella duryi (Wetherby 1879) (see Table 1).

Table 1. The aquatic molluscan assemblages in the two localities where Gyraulus chinensis was found.

\begin{tabular}{lcc}
\hline List of species & Dvưr Králové & Praque \\
\hline Galba truncatula & & 5 \\
Radix cf. peregra & & 25 \\
Physella acuta & 20 & 8 \\
Gyraulus chinensis & 2 & 8 \\
Planorbella duryi & & 3 \\
Ferrissia clessiniana & 30 & \\
\hline
\end{tabular}

\section{Discussion}

In the Czech Republic only three other species of $G y$ raulus - G. albus (O.F. Müller, 1774), G. parvus (Say, 1817), G. crista (Linnaeus, 1758) - have been recorded from greenhouses (HORSÁK et al. 2004, BERAN unpublished records). Our finding of $G$. chinensis was the first in the Czech Republic, and its occurrence in other greenhouses is possible. Survival of this snail in the Czech Republic in the wild seems unlikely to us however, it might be possible in artificially heated environments.

\section{References}

ANDERSON R., 2005: An annotated list of non-marine Mollusca of Britain and Ireland. - Journal of Conchology, 38 (6): 607-637.

BERAN L. 2002: Vodní měkkýši České republiky - rozšíření a jeho změny, stanoviště, šíření, ohrožení a ochrana, červený seznam [Aquatic molluscs of the Czech Republic - distribution and its changes, habitats, dispersal, threat and protection, Red List]. - Sborník př́rodovědného klubu v Uh. Hradišti, Supplementum 10, 258 pp.

Brown D.S., Gracio M.A.A. \& MeIER-Brook C., 1999: The Asian freshwater snail Gyraulus chinensis (Dunker, 1848) (Planorbidae) in West Africa and Europe. - Journal of African Zoology, 112: 203-213.

FALKNER G., 1990: Binnenmollusken. - In: Steinbachs Naturführer. Weichtiere. Europäische Meeres- und Binnenmollusken, FECHTER R. \& FALKNER G. (eds), Mosaik Verlag, München: 112-273.

GlÖER P. \& MEIER-BRoOK C., 2003: Süßwassermollusken. Ein Bestimmungsschlüssel für die Bunderepublik Deutschland. 13. Auflg. - Deutscher Jugendbund für Naturbeobachtung, Hamburg, 134 pp.

GLÖER P. \& ZETTLER M.L., 2005: Kommentierte Artenliste der Süßwassermollusken Deutschlands. - Malakologische Abhandlungen, 23: 3-26.

HORSÁK M., DVOŘÁK L. \& JUŘIČKOVÁ L., 2004: Greenhouse gastropods of the Czech Republic: current stage of research. - Malakológiai Tájékoztató, 22: 141-147.

MeIER-Brook C., 2002: What makes an aquatic ecosystem susceptible to mollusc invasions? - Collectanea Malacologica, ConchBooks, Hackenheim, pp. 405-417.

PROSCHWITZ T. VON, 2005: Faunistiskt nytt 2004 - snäckor, sniglar och musslor inklusive något om kinesisk skivsnäcka Gyraulus chinensis (Dunker) och amerikansk tropiksylsnäcka Subulina octona (Bruguière) - två för Sverige nya människospridda snäckarter [Faunistical news from the Göteborg Natural History Museum 2004 - snails, slugs and mussels]. - Göteborgs Naturhistoriska Museum, Arstryck 2005: 35-61.

PRUNER L. \& MíkA P., 1996. Seznam obcí a jejich částí v České republice s čísly mapových polí pro sítové mapování fauny [List of settlements in the Czech Republic with associated map field codes for faunistic grid mapping system]. - Klapalekiana, 32, Suppl.: 1-175.

Stratz Ch., 2005: Das Afrikanische Kegelchen Afropunctum seminium (Morelet 1873) im Tropenwaldhaus des Ökologisch-Botanischen Gartens der Universität Bayreuth (Nordbayern). - Club Conchylia, 37 (1-2): 15-19. 


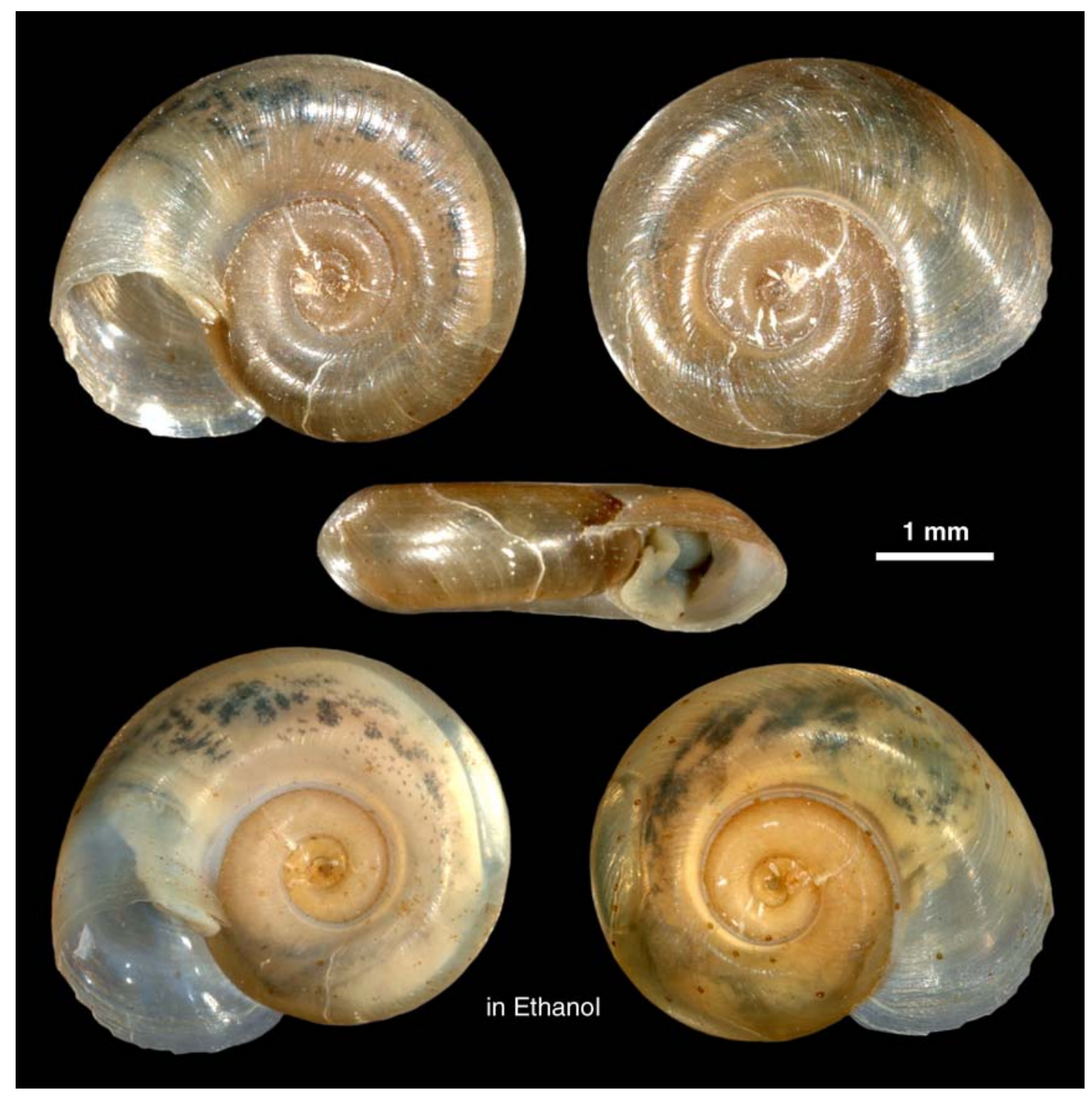

Fig. 1. Shell and body of Gyraulus chinensis from locality 1. (Dvůr Králové nad Labem). Photo P. Glöer. 


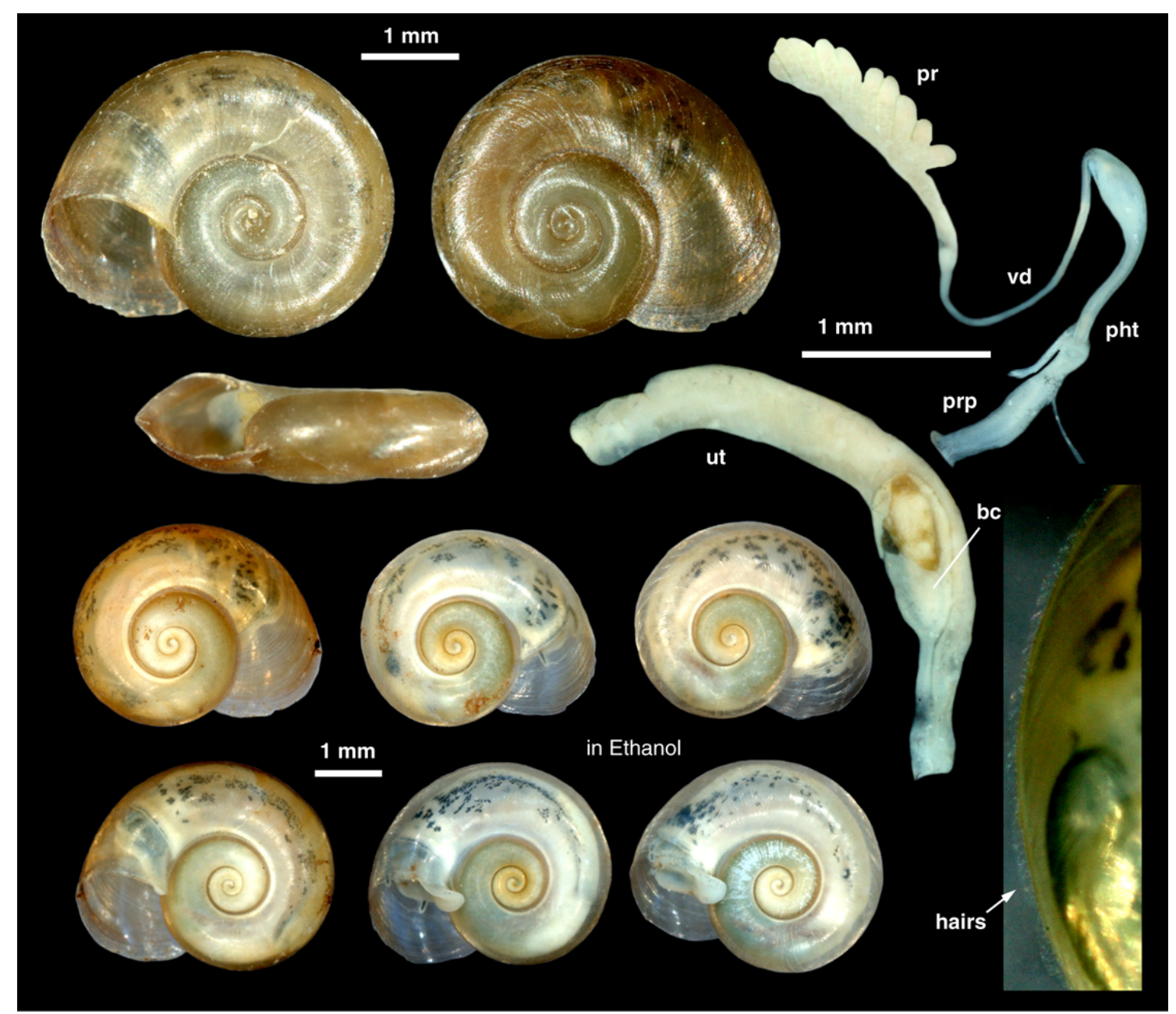

Fig. 2. Shell, body and reproductive system of Gyraulus chinensis from locality 2. (Prague). Photo P. Glöer. 